\title{
LOCATING CONVECTION IN LANDFALLING TROPICAL CYCLONES: A GIS-BASED ANALYSIS OF RADAR REFLECTIVITIES AND COMPARISON TO LIGHTNING-BASED OBSERVATIONS
}

\author{
Corene J. Matyas \\ Department of Geography \\ University of Florida \\ 3141 Turlington Hall \\ Gainesville, FL 32611-7315
}

\begin{abstract}
Researchers have utilized radar reflectivity returns and lightning flashes separately and together to locate convection with tropical cyclones (TCs). Most studies utilizing both datasets have examined TCs over the ocean, while landfall observations have been limited to a few TCs. This study employs a GIS to delineate regions of high radar reflectivity values within 45 landfalling TCs. The percentage of convective regions contained within each quadrant placed relative to storm motion and deep-layer vertical wind shear is calculated. These percentages are then compared to those from previous studies of quadrantbased lightning flash locations. Results indicate that the GIS-based radar analysis may be identifying TC regions that are electrically active. Both the radar- and lightning-based analyses show that convection shifts from the right to the front of the storm as forward velocity increases. Convection is located left of the shear vector when storm motion is $45-135^{\circ}$ counterclockwise from the shear vector, and downshear when shear-minus-motion angles are $315-45^{\circ}$. Additionally, storms that became extratropical within 72 hours of landfall had more convection forward of the circulation center and left of the shear vector, and may produce less lightning than the remaining TCs. [Key words: tropical cyclone, radar, GIS, lightning, rainfall, landfall, storm quadrant.]
\end{abstract}

\section{INTRODUCTION}

As they move over land, tropical cyclones (TCs) can produce heavy rainfall that leads to widespread flooding (e.g., Konrad, 2001; Tootle et al., 2005; Schumacher and Johnson, 2006), and TC-induced flooding has contributed to hundreds of fatalities within the United States (Rappaport, 2000; Ashley and Ashley, 2008). TC rain fields are comprised of both stratiform and convective clouds (e.g., Barnes et al., 1983; Jorgensen, 1984; Yokoyama and Takaybu, 2007; Matyas, 2009) and both cloud types contribute to high TC rainfall totals (Shepherd et al., 2007). GIS-based methods have been utilized to quantify spatial patterns in the rain fields of TCs in their entirety (e.g., Matyas, 2007, 2008), but these methods have not been applied to regions producing high rain rates. The high rainfall rates produced by convective clouds can cause flooding in a relatively short amount of time (Geerts et al., 2000; Elsberry, 2002), and damaging winds may be contained within regions of convective rainfall (Willoughby et al., 1984; Powell, 1987; Wakimoto and Black, 1994). Thus, identifying where convective regions exist as a TC moves inland is an important task, and one that is ideally suited for geographers who employ spatial analysis techniques 
(e.g., Konrad, et al., 2002; Knight and Davis, 2007; Shepherd et al., 2007; Matyas, 2008, 2009; Konrad and Perry, 2010).

As the co-location of lightning flashes with high radar reflectivity values indicates that strong updrafts are present to loft hydrometeors above the freezing level (e.g., Zipser and Lutz, 1994), and that high rainfall rates are also occurring (e.g., Cecil et al., 2005), researchers have utilized both types of data to indicate the presence of strong convection (e.g., Williams, et al., 1992; Murphy and Konrad, 2005; Nesbitt et al., 2006; Liu and Zipser, 2008; Squires and Businger, 2008). Recent analyses of data from the lightning sensor and precipitation radar on board the Tropical Rainfall Measuring Mission (TRMM) satellite have shown that convection located over land produces more lightning than that located over the ocean, and that the radar reflectivity profiles of these systems also differ (Nesbitt et al., 2000; Cecil and Zipser, 2002; Cecil et al., 2002; Toracinta et al., 2002). As TCs contain relatively weak updrafts, have relatively small quantities of supercooled liquid water, and produce a large portion of their rainfall through stratiform precipitation processes, it is not surprising that they produce less lightning than continental-based thunderstorms (Jorgensen, 1984; Lyons and Keen, 1994; Black and Hallett, 1999; Cecil and Zipser, 2002; Cecil et al., 2002).

Although the TRMM-based studies have provided a deeper understanding of the differences in land-based and oceanic convection, these studies have not contained a large sample of observations from TCs moving over land. Studies examining convection within landfalling TCs have most commonly employed lightning flash data from the National Lightning Detection Network (NLDN) (e.g., Lyons and Keen, 1994; Molinari et al., 1994, 1999; Samsury and Orville, 1994; Corbosiero and Molinari, 2002, 2003; McCaul et al., 2004) and/or reflectivity values from ground-based radar (e.g., Parrish et al., 1982; Bluestein and Hazen, 1989; Burpee and Black, 1989; Medlin et al., 2007; Arndt et al., 2009; Matyas, 2009). These studies have shown that lightning flash rates and/or the spatial extent of convection can vary as TCs make landfall. However, only four of the NLDN studies incorporated radar reflectivity data, and the authors only sampled one or two TCs in each study. Corbosiero and Molinari $(2002,2003)$ examined lightning data for 35 landfalling TCs, but associations between lightning flash locations and radar reflectivity patterns have not been undertaken for such a large sample of landfalling TCs.

Working toward this goal, the current study compares the locations of convective regions derived through a spatial analysis of radar reflectivity returns to earlier studies of landfalling TCs that identified convectively active regions with lightning flash data. A GIS is employed to delineate regions of high reflectivity values and to determine their size and location. Next, they are placed into quadrants according to their position relative to storm motion and the direction of the vertical wind shear. Comparisons are then made to the results of Corbosiero and Molinari (2002, 2003) (hereafter referred to as CMO2 and CM03), who determined which TC quadrants had the highest cloud-to-ground (CG) lightning flash densities under differing environmental conditions. The CM02 study accounted for the speed and direction of the 200-850 hPa vertical wind shear, while CM03 additionally considered how storm motion corresponded with the distribution of CG flashes for the same sample of TCs. If the current study places the radar-derived convective regions into the same 
motion- and shear-based quadrants as $\mathrm{CMO3}$, this will indicate that GIS-based methods to delineate the most convectively active regions of landfalling TCs may also be identifying electrically active regions. Stepping beyond the work of CM03, the current study also examines separately TCs that became extratropical within 72 hours of landfall.

\section{DATA}

Regions of high reflectivity were identified through an analysis of base reflectivity radar returns from the Weather Surveillance Radar-1988 Doppler (WSR-88D) network. Reflectivity data were obtained online from the National Climatic Data Center (NCDC) (http://www.ncdc.noaa.gov/nexradinv/). As Level III base reflectivity data (OFCM, 2006) are available from all WSR-88D sites extending back to 2001 and from most sites since 1995, these data were selected for analysis. When Level III data were unavailable for 1995-2001, data were extracted from the lowest scan elevation of the Level II dataset and rounded to the nearest $5 \mathrm{dBZ}$. To qualify for analysis, the entire rain-field span must have been within the $235 \mathrm{~km}$ range of the WSR-88D network for 24 hours after landfall. Forty-five landfalls of 40 TCs during 1995-2008 were analyzed in this study (Table 1). As reflectivity data are partially absent from the NCDC archives during the landfall periods for most 1998 TCs, these storms were not included in the study. Radar data were acquired for the time of landfall and eight three-hourly periods thereafter for a total of 405 observation times.

The positions of the TC circulation centers at the time of landfall were taken from the National Hurricane Center (NHC)'s Hurricane Season Tropical Cyclone Report (http://www.nhc.noaa.gov/pastall.shtml). This report was also utilized to identify the times at which TCs were classified as extratropical by the NHC. The Hurricane Database (HURDAT) maintained by the NHC was utilized to determine TC positions and storm motion at all other analysis times. Six-hourly observations beginning at 0000 UTC for all TCs in the North Atlantic Ocean basin are available within HURDAT. These data were interpolated linearly to produce observations every three hours beginning at the time of a TC's landfall.

Data pertaining to the velocity and direction of the deep-layer vertical wind shear were acquired from the Statistical Hurricane Intensity Scheme (SHIPS) database (DeMaria and Kaplan, 1994; DeMaria et al., 2005). Similar to HURDAT, SHIPS data are also available at 0000, 0600, 1200, and 1800 UTC and were linearly interpolated to the time of landfall and three-hourly periods thereafter for the current study. The deep-layer vertical wind shear values in the SHIPS database represent the difference between the 200 and $850 \mathrm{hPa}$ winds calculated for an annular region 200-800 $\mathrm{km}$ from the circulation center of each TC.

\section{ANALYSIS}

Data from each three-hourly observation time were analyzed separately. The radar data were first georeferenced using the NCDC's Weather and Climate toolkit. Once imported into the GIS, the mosaic tool combines data from adjoining WSR-88D 
Table 1. Storms Analyzed in the Current Study

\begin{tabular}{|c|c|c|c|c|}
\hline Tropical cyclonea & Year & $\begin{array}{c}\text { Time and date analysis } \\
\text { begins }\end{array}$ & $\begin{array}{l}\text { No. inner core } \\
\text { regions }\end{array}$ & $\begin{array}{l}\text { No. outer } \\
\text { regions }\end{array}$ \\
\hline Erin* & 1995-1 & 0630 UTC 2 Aug & 7 & 13 \\
\hline Erin* & $1995-2$ & 1600 UTC 3 Aug & 7 & 19 \\
\hline Opal* & 1995 & 2200 UTC 4 Oct & 5 & 20 \\
\hline Bertha* & 1996 & 2000 UTC 12 Jul & 7 & 40 \\
\hline Danny* & 1997 & 0900 UTC 18 Jul & 10 & 17 \\
\hline Bonnie & 1998 & 0400 UTC 27 Aug & 6 & 10 \\
\hline Bret* & 1999 & 0000 UTC 23 Aug & 9 & 21 \\
\hline Dennis* & 1999 & 2100 UTC 4 Sep & 2 & 9 \\
\hline Floyd* & 1999 & 0630 UTC 16 Sep & 3 & 10 \\
\hline Gordon & 2000 & 0300 UTC 18 Sep & 0 & 0 \\
\hline Helene & 2000 & 1200 UTC 22 Sep & 5 & 18 \\
\hline Allison & 2001 & 2100 UTC 5 Jun & 7 & 11 \\
\hline Barry & 2001 & 0500 UTC 6 Aug & 5 & 6 \\
\hline Bertha & 2002 & 0200 UTC 5 Aug & 3 & 13 \\
\hline Fay & 2002 & 0900 UTC 7 Sep & 3 & 10 \\
\hline Hanna & 2002 & 0800 UTC 14 Sept & 1 & 11 \\
\hline Isidore & 2002 & 0600 UTC 26 Sep & 4 & 12 \\
\hline Bill & 2003 & 1900 UTC 30 Jun & 3 & 30 \\
\hline Claudette & 2003 & 1530 UTC 15 Jul & 10 & 1 \\
\hline Grace & 2003 & 1100 UTC 31 Aug & 2 & 9 \\
\hline Frances & 2004-1 & 0430 UTC 5 Sep & 2 & 10 \\
\hline Frances & $2004-2$ & 1800 UTC 6 Sep & 0 & 27 \\
\hline Gaston & 2004 & 1400 UTC 29 Aug & 15 & 6 \\
\hline Ivan & 2004 & 0700 UTC 16 Sep & 11 & 34 \\
\hline Jeanne & 2004 & 0400 UTC 26 Sep & 19 & 12 \\
\hline Arlene & 2005 & 1900 UTC 11 Jun & 4 & 4 \\
\hline Cindy & 2005 & 0300 UTC 6 Jul & 7 & 29 \\
\hline Dennis & 2005 & 1930 UTC $10 \mathrm{Jul}$ & 5 & 7 \\
\hline Katrina & 2005 & 1110 UTC 29 Aug & 7 & 24 \\
\hline Rita & 2005 & 0730 UTC 24 Sep & 10 & 38 \\
\hline Tammy & 2005 & 2300 UTC 5 Oct & 2 & 10 \\
\hline Alberto & 2006 & 1630 UTC Jun 13 & 1 & 2 \\
\hline Ernesto & 2006-1 & 0300 UTC 30 Aug & 7 & 23 \\
\hline Ernesto & 2006-2 & 0330 UTC 1 Sep & 2 & 0 \\
\hline Barry & 2007 & 1400 UTC 2 Jun & 1 & 6 \\
\hline Erin & 2007 & 1030 UTC 16 Aug & 7 & 16 \\
\hline Humberto & 2007 & 0700 UTC 13 Sep & 3 & 3 \\
\hline Dolly & 2008 & 1830 UTC 23 Jul & 7 & 18 \\
\hline Edouard & 2008 & 1200 UTC 5 Aug & 2 & 2 \\
\hline Fay & 2008-1 & 0900 UTC 19 Aug & 11 & 16 \\
\hline Fay & $2008-2$ & 1900 UTC 21 Aug & 6 & 28 \\
\hline Fay & $2008-3$ & 0630 UTC 23 Aug & 2 & 27 \\
\hline Gustav & 2008 & 1500 UTC 1 Sep & 10 & 27 \\
\hline Hanna & 2008 & 0730 UTC 6 Sep & 2 & 7 \\
\hline Ike & 2008 & 0700 UTC 13 Sep & 6 & 12 \\
\hline
\end{tabular}

a Storms indicated by an asterisk $\left(^{*}\right)$ are those also analyzed in CM02 and CM03. 
stations onto a raster grid. The highest reflectivity value was retained at locations where data are available from multiple WSR-88D sites. Although this method has been shown to favor returns from over-calibrated radars (Williams et al., 2005; Zhang et al., 2005; Delobbe and Holleman, 2006), Parker and Knievel (2005) found that this problem is minimized when examining reflectivity values equal to or greater than $40 \mathrm{dBZ}$. In general, reflectivity values of 35-41 dBZ have been used to delineate the edge of convective precipitation regions within TCs (e.g., Parrish et al., 1982; Burpee and Black, 1989; Blackwell, 2000; Matyas, 2009, 2010). As researchers have found that the highest lightning flash densities also occur once reflectivity values reach 40 dBZ (Proctor, 1991; Toracinta et al., 1996; Tapia et al., 1998; Steiger et al., 2007), 40 $\mathrm{dBZ}$ was used as the threshold value to delineate convective regions in the current study. Next, the data were interpolated in $5 \mathrm{dBZ}$ increments using inverse distance weighting, and polygons were created. The latitude and longitude of each polygon's centroid was determined and its area was calculated.

Only polygons larger than $500 \mathrm{~km}^{2}$ in area that enclose reflectivity values of 40 $\mathrm{dBZ}$ or greater were analyzed further. This area measurement approximates an average-sized thunderstorm, which, according to the National Severe Storm Laboratory (NSSL, 2006), has a diameter of $15 \mathrm{mi}(24 \mathrm{~km})$, yielding a circle with an area of 452 $\mathrm{km}^{2}$. The CM02 and CM03 studies only utilized time periods with high lightning flash densities. Thus, including smaller regions of $40 \mathrm{dBZ}$ reflectivity values might have caused the results of the current study to differ from those of CM02 and CM03 because convective regions that are less than $500 \mathrm{~km}^{2}$ in area are not as likely as their larger counterparts to produce high lightning flash rates. Additionally, large regions of high reflectivity pose a greater risk of flooding, as high rainfall rates cover a large area, which leads to a longer event duration. Figure 1 shows the convective regions that were analyzed during the nine observation times for Hurricane Erin (1995).

Spherical trigonometry was utilized to calculate the distance and bearing of each polygon centroid relative to the circulation center of the TC. Polygons with centroids located outside of a $300 \mathrm{~km}$ radius of the circulation center were removed from consideration to render the current study comparable to CMO2 and CM03. The centroid locations were then subtracted from the direction of the storm motion and heading of the vertical wind shear. After this calculation, polygon centroids with bearings 0-90 $0^{\circ}$ were located in the right-front quadrant, when storm motion is considered, and the downshear right quadrant when the direction of vertical wind shear is considered (Fig. 2).

Observation times were grouped according to the speeds of storm motion and vertical wind shear in the same manner as that in $\mathrm{CMO} 2$ and $\mathrm{CM} 03$. Slow-moving TCs have forward velocities under $3 \mathrm{~m} \mathrm{~s}^{-1}$, while moderate and fast-moving TCs have forward speeds of 3-6 $\mathrm{m} \mathrm{s}^{-1}$ and greater than $6 \mathrm{~m} \mathrm{~s}^{-1}$, respectively. Vertical wind shear was deemed to be weak, moderate, and strong at velocities of $<5 \mathrm{~m} \mathrm{~s}^{-1}, 5-10 \mathrm{~m} \mathrm{~s}^{-1}$, and $>10 \mathrm{~m} \mathrm{~s}^{-1}$. Also, in keeping with $\mathrm{CMO} 2$ and CM03, convective regions within $100 \mathrm{~km}$ of the circulation center, which is considered to be the core of the storm, were examined separately from those located 100-300 km from the storm center, which they termed the outer region. The percentage of convective regions contained within each motion- and shear-based quadrant were calculated. In addition, 


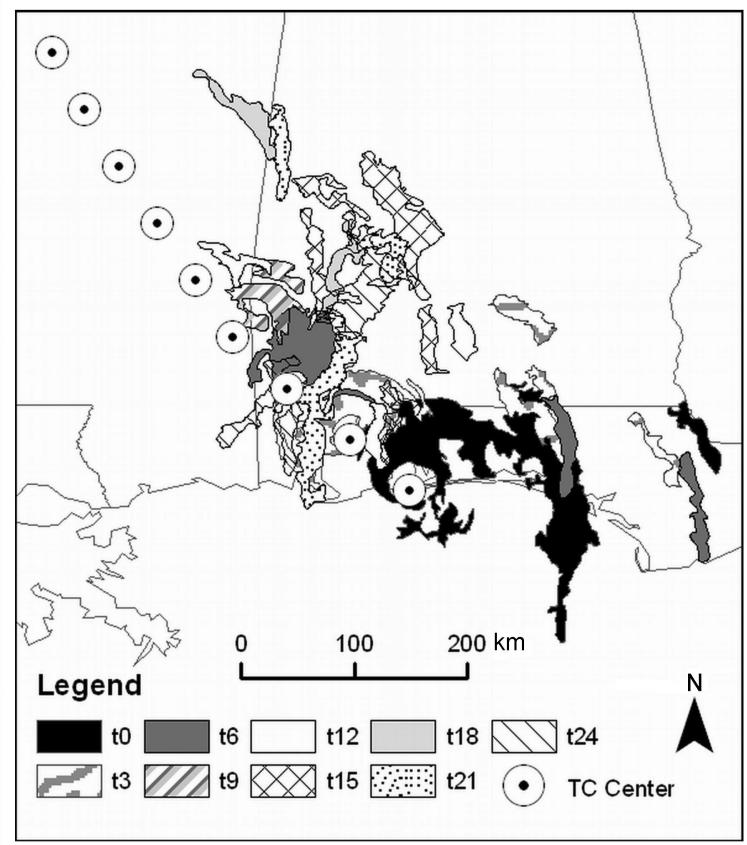

Fig. 1. The $40 \mathrm{dBZ}$ polygons analyzed at each three-hourly observation time during the second landfall of Erin (1995).

the current study separated TCs according to their status as extratropical cyclones. Observations from TCs that became extratropical within 72 hours of landfall (ET72) were grouped separately from those that either did not make this transition, or made this transition beyond 72 hours of landfall.

As this study compared the locations of convective regions identified through a GIS-based radar analysis to those discussed by CM02 and CM03 (Corbosiero and Molinari, 2002, 2003), it is appropriate to briefly summarize their methods. They identified convective rainfall through a count of CG flashes obtained from the NLDN database, whose sensors detect to a range of $400 \mathrm{~km}$. Thirty-five TCs during 19851999 were analyzed when their centers were located within $400 \mathrm{~km}$ of at least one sensor. Although they did not differentiate TCs transitioning into extratropical cyclones from those that did not, an inspection of the times listed in their Table 1 shows that analysis ceased either one hour prior to or on the hour that a TC was classified as extratropical by the NHC. They grouped observations into 12-hourly periods centered about the time of each European Center for Medium-Range Weather Forecast analysis from which the vertical wind shear vectors were calculated. During each period, they noted the motion- and shear-based quadrant containing the highest flash density. The current study converts the counts of these quadrants presented in Figures 2 and 4 from $\mathrm{CMO} 2$ and 3 and 4 from $\mathrm{CMO} 3$ into percentages. CMO2 and $\mathrm{CMO} 3$ only used data from observation times containing a high density of CG flashes, which yielded 106 inner-core and 154 outer-region observation periods. 


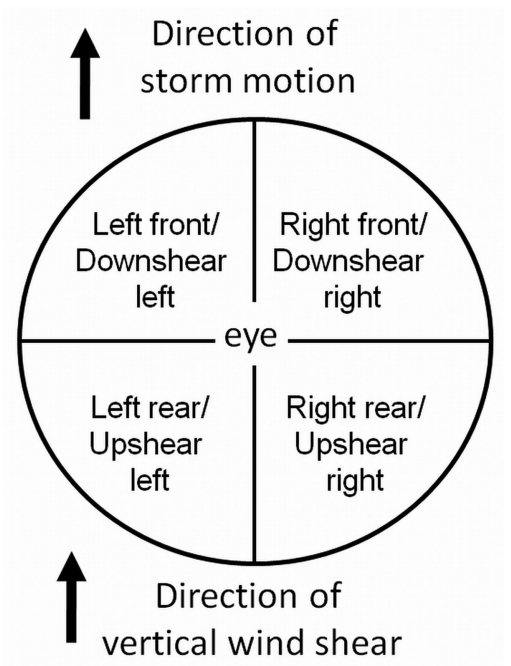

Fig. 2. Bird's-eye view of a tropical cyclone with quadrant names corresponding to storm motion and vertical wind shear directed toward the top of the page.

They also noted the angle between the shear and motion vectors for all 303 original observation periods.

\section{RESULTS AND DISCUSSION}

There are 916 regions of convection larger than $500 \mathrm{~km}^{2}$ located within $300 \mathrm{~km}$ of the circulation centers of the TCs. A total of 294 observation times have at least one convective region meeting the minimum area requirement and data for vertical wind shear and storm motion. There are 167 (243) times featuring at least one convective region within the inner core (outer region). An additional 393 convective regions located 300-500 km from the circulation center also met the minimum area requirement. This suggests that $300 \mathrm{~km}$ may be too small of a radius to define the extent of the outer rainbands. However, the current study only utilized regions located with the $300 \mathrm{~km}$ radius, as this was the extent employed by CM02 and CM03.

Overall, the locations of the radar-derived convective regions agree well with those identified through the analysis of CG flashes by CM03. As the best match between quadrant percentages in the current study and those by Corbosiero and Molinari occurs when storm motion alone is considered, the results of the analyses based upon storm-motion vectors will be discussed first. When vertical wind shear is considered in absence of storm motion, the current study finds more convection left of shear rather than in both downshear quadrants. However, once accounting for fact that the distribution of angles between storm motion and vertical wind shear differed between the two studies, the results of the current study support those of $\mathrm{CMO} 3$ for vertical wind shear according to their Figure 8. The current study confirms that both vertical wind shear and storm motion influence where convective precipitation develops within TCs, supporting the work of CM03. 


\section{Storm Motion}

Forward velocities for TCs in the current study range from $0.6 \mathrm{~m} \mathrm{~s}^{-1}$ for Fay (2008) to $15.6 \mathrm{~m} \mathrm{~s}^{-1}$ for Opal (1995). The majority of the observation times (48\%) feature TCs with forward velocities in the 3-6 $\mathrm{m} \mathrm{s}^{-1}$ range. Fast-moving TCs comprise $32 \%$ of the observation times and, with an average size of $3215 \mathrm{~km}^{2}$, the convective regions of these TCs are more than twice as large as those within slow-moving TCs. Regardless of forward velocity or distance from the storm center, most of the convective regions $(48 \%)$ are located in the right front quadrant of the storm. In general, the number of convective regions is high in the right rear quadrant and low in the left front quadrant for slow-moving TCs; but, as forward velocity increases, convection diminishes in the right rear quadrant and increases in the left front quadrant (Fig. 3).

Both modeling (Shapiro, 1983; Frank and Ritchie, 1999; Kimball, 2008) and observational studies (Lonfat et al., 2004; Chen et al., 2006) have found that, as forward motion increases, rainfall shifts counterclockwise from the right side to the front of a TC. The results of the current study and CM03 agree with these previous studies (Fig. 3). Furthermore, dividing the TCs into inner core and outer regions reveals that this shift occurs primarily in the outer regions of the TCs. The current study finds that, in the outer region, nearly half of the convection is located in the right rear quadrant within slow-moving TCs. When TCs move at moderate speeds, convection is reduced in the right rear quadrant, but increases in the right and left front quadrants. This trend continues for fast-moving TCs, as more than $80 \%$ of the convection is located in the forward quadrants. The modeling work of Shapiro (1983) provides an explanation for the counterclockwise shift in convection as TCs move faster. The maximum inflow angle and boundary-layer convergence tend to be located in the right front quadrant of a TC. Frictional convergence imparted by the storm's motion enhances convection, and this enhancement is focused primarily ahead of the circulation center when TCs move fast.

A further explanation for the counterclockwise shift lies in the fact that many TCs approaching the coastline of the United States transition into extratropical cyclones and, as they do so, convection shifts in a counterclockwise direction (Milrad et al., 2009). When a TC is restructured into an extratropical cyclone, convection is enhanced ahead of the storm as the moist air on the right side of the storm is uplifted by the cooler and drier air to the left of the storm (Ritchie and Elsberry, 2001; Atallah and Bosart, 2003). Drier air enters the storm's circulation behind the center and diminishes convection there. Forward velocity tends to increase as the transition progresses (Jones et al., 2003), and the combined effects of storm motion and structural changes likely account for the overall counterclockwise shift in convective activity. Hart and Evans (2001) found that nearly half of all Atlantic Basin TCs become extratropical. Of the 45 landfalls examined in the current study, 20 belong to TCs that are classified as extratropical within 72 hours of landfall. Sixteen of the 32 TCs examined by CM03 became extratropical, indicating that both studies contain an appropriate sampling of these storms.

Although the current study and that of $\mathrm{CMO} 3$ identify the same quadrant as containing the highest percentage of convection, one difference does exist with regard to the second highest quadrant (Fig. 3B). For convective activity in the outer regions 


\begin{tabular}{|c|c|}
$\%<3 \mathrm{~m} \mathrm{~s}^{-1}$ & \multicolumn{2}{c|}{$\% 3-6 \mathrm{~m} \mathrm{~s}^{-1}$} \\
\hline 23 & 49 \\
28 & 41 \\
\hline 11 & 17 \\
9 & 22 \\
\hline 29 & 38 \\
28 & 47 \\
\hline 8 & 25 \\
12 & 13 \\
\hline
\end{tabular}

\begin{tabular}{|c|c|c|c|}
\hline \multicolumn{2}{|c|}{$\%>6 \mathrm{~m} \mathrm{~s}^{-1}$} & \multicolumn{2}{|c|}{ No. obs. } \\
\hline 35 & 43 & 30 & 45 \\
\hline 21 & 67 & 65 & 128 \\
\hline 9 & 13 & 10 & 21 \\
\hline 9 & 3 & 26 & 29 \\
\hline
\end{tabular}

A. Inner core (0-100 km)

\begin{tabular}{c|c|c|c|c|}
\multicolumn{2}{c}{$\%<3 \mathrm{~m} \mathrm{~s}^{-1}$} & \multicolumn{2}{c|}{$\% 3-6 \mathrm{~m} \mathrm{~s}^{-1}$} \\
\hline 15 & 37 \\
2 & 39 \\
\hline 9 & 39 \\
12 & 47 \\
\hline 9 & 47 \\
\hline 18 & 46 \\
\hline 9 & 36 \\
\hline
\end{tabular}

$$
\%>6 \mathrm{~m} \mathrm{~s}^{-1}
$$

\begin{tabular}{|c|c|}
\hline 10 & 48 \\
32 & 51 \\
\hline 12 & 30 \\
3 & 14 \\
\hline
\end{tabular}

No. obs.

\begin{tabular}{|c|c|}
\hline 16 & 68 \\
102 & 308 \\
\hline 21 & 49 \\
48 & 210 \\
\hline
\end{tabular}

B. Outer region $(100-300 \mathrm{~km})$

Fig. 3. Convection locations for the (A) inner $100 \mathrm{~km}$ and (B) outer 100-300 km of tropical cyclones when quadrants are based on storm motion for Corbosiero and Molinari (2003) (top line of each box) and this study (bottom line of each box). The top left square in each box is the left front quadrant. The shaded quadrant contains the largest percentage of convection.

of fast-moving TCs, the current study finds that more convection is located in the left front quadrant than in the right rear, while $\mathrm{CMO} 3$ found that the right rear quadrant had the second-highest number of CG flash counts. A higher percentage of the observations in the current study are located in the outer region than in the CM03 study (Table 2). The lower percentage in the CM03 study could be attributed to the outer regions of offshore TCs being out of range of the NLDN. CM03 utilized time 
Table 2. Percentage of Observations Located within the Inner $100 \mathrm{~km}$ and the Outer 100-300 km for Different Velocities of Storm Motion and Vertical Wind Shear for Corbosiero and Molinari $(2002,2003)$ and the Current Study

\begin{tabular}{lcccc}
\hline \hline Zone & CM03 motion & This study motion & CM02 shear & This study shear \\
\hline & & Low & & \\
0-100 km & 40 & 24 & 37 & 25 \\
$100-300 \mathrm{~km}$ & 60 & 76 & 63 & 75 \\
& & Medium & & \\
$0-100 \mathrm{~km}$ & 41 & 29 & 38 & 21 \\
100-300 km & 59 & 71 & 62 & 79 \\
& & High & & \\
$0-100 \mathrm{~km}$ & 41 & 22 & 47 & 29 \\
100-300 km & 59 & 78 & 53 & 71 \\
\hline
\end{tabular}

periods when the TC center was within $400 \mathrm{~km}$ of the sensor network. However, for the entire $300 \mathrm{~km}$ radius of the TC to be within sensor range, the circulation center must not be located more than $100 \mathrm{~km}$ offshore. The tracks of the TCs during the time periods listed in CM02's Table 1 are plotted in Figure 4, which shows that many observation periods occurred when TC centers were more than $100 \mathrm{~km}$ offshore. The removal of low flash count periods from their study may have alleviated some of this problem, but it is still possible that the edges of the rain fields closest to the coastline contained sufficiently high flash counts to remain in the analysis while the other side of the storm was out of sensor range. Thus, the current study may present a more complete approximation of the locations of outer-region convection. To more accurately assess electrically active regions within the entire TC as it nears landfall, future research might employ data from the long-range lightning detection network (e.g., Squires and Businger, 2008) and/or the TRMM lightning sensor (e.g., Cecil et al., 2002).

\section{Vertical Wind Shear}

As TCs making landfall in the United States traverse latitudes where strong westerly winds may increase vertical wind shear, it follows that only $14 \%$ of observation times occur when vertical wind shear is weak. Through observational and modeling studies, previous researchers have cited vertical wind shear as a mechanism that aids the development of convective regions within TCs (Frank and Ritchie, 2001; Black et al., 2002; Rogers et al., 2003; Lonfat et al., 2007; Wang et al., 2009). Hence, it is not surprising that $61 \%$ of the convective regions occur when vertical wind shear is strong and that these regions have a larger size on average at $1899 \mathrm{~km}^{2}$ when compared to convective regions that exist when shear velocity is weak to moderate. 


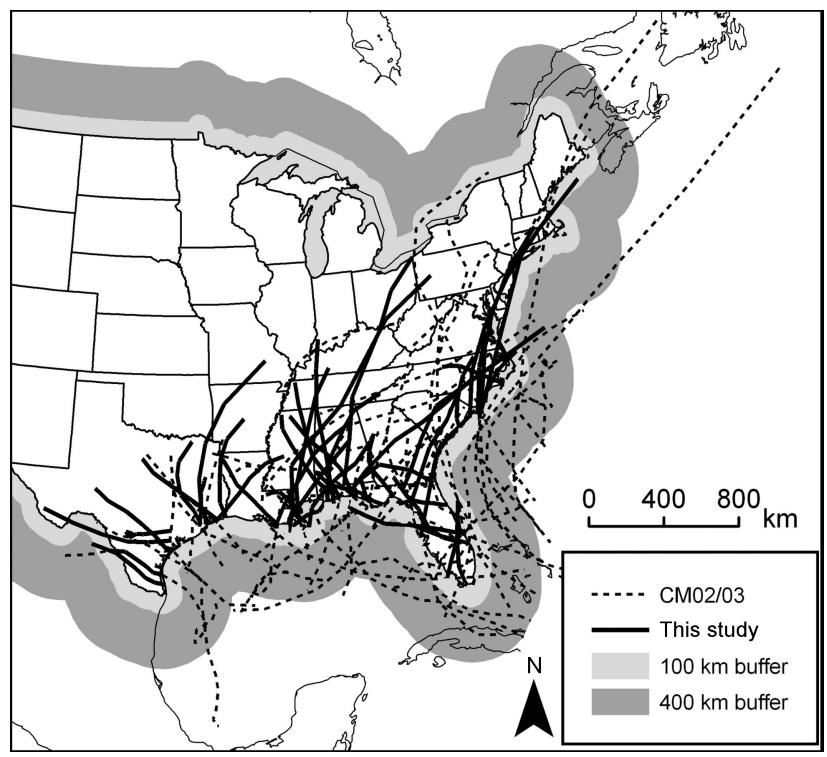

Fig. 4. Tracks of tropical cyclones examined in the current study and that of Corbosiero and Molinari (2002, 2003), showing that many of their observations occurred when part of the TC was out of range of the lightning detection network.

Strong vertical wind shear is known to produce a wavenumber-one asymmetry in TC rain fields (Frank and Ritchie, 1999, 2001; Rogers et al., 2003; Lonfat et al., 2004; Chen et al., 2006; Cecil, 2007; Lonfat et al., 2007) and the results of the current study and $\mathrm{CMO} 2$ concur (Fig. 5). Convection tends to be reduced upshear as downward vertical motion is enhanced by horizontal temperature gradients and a vertical circulation that develops to compensate for the tilting of the vortex under vertical wind shear (Jones, 1995; DeMaria, 1996; Frank and Ritchie, 1999; Jones, 2000). The current study finds that the majority of the convection is located left of the shear vector (Fig. 5) regardless of the strength of the shear, as did Black et al. (2002). The highest CG flash rates found by $\mathrm{CMO} 2$ occurred in either the downshear left or downshear right quadrants. This counterclockwise shift in convection from $\mathrm{CMO} 2$ to the current study occurs because the studies contain different angles between the direction of the vertical wind shear and the heading of the storm. CM03 explored how differing angles between vertical wind shear and storm motion affected the locations where convection developed (their Fig. 8).

After subtracting the angle of storm motion from the direction of the vertical wind shear (shear minus motion), the CM03 study contained many more observation periods with shear-motion difference angles of $315-45^{\circ}$ than does the current study, which features more angles of $135-225^{\circ}$ (Table 3). This means that the right front quadrant, which is favored for motion-induced convection, frequently coincided with both downshear quadrants in $\mathrm{CM02}$, but mainly with the downshear and upshear left quadrants in the current study. Furthermore, nearly $54 \%$ of the convective regions in the current study occur when the shear-motion angle difference is 45- 


$\%<5 \mathrm{~m} \mathrm{~s}^{-1}$
\begin{tabular}{|c|c|}
\hline 30 & $35-10 \mathrm{~m} \mathrm{~s}^{-1}$ \\
25 & 17 \\
\hline 17 & 17 \\
33 & 25 \\
\hline
\end{tabular}

\begin{tabular}{|c|c|c|c|}
\hline \multicolumn{2}{|c|}{$\%>10 \mathrm{~m} \mathrm{~s}^{-1}$} & \multicolumn{2}{|c|}{ No. obs. } \\
\hline 63 & 30 & 52 & 39 \\
\hline 63 & 29 & 137 & 62 \\
\hline 5 & 2 & 7 & 8 \\
\hline 6 & 2 & 36 & 16 \\
\hline
\end{tabular}

\section{A. Inner core $(0-100 \mathrm{~km})$}

$$
\%<5 \mathrm{~m} \mathrm{~s}^{-1} \quad \% 5-10 \mathrm{~m} \mathrm{~s}^{-1}
$$

\begin{tabular}{|c|c|c|c|}
\hline 38 & 36 & 29 & 59 \\
\hline 40 & 12 & 53 & 22 \\
\hline 18 & 8 & 1 & 11 \\
\hline 29 & 19 & 16 & 8 \\
\hline
\end{tabular}

$\%>10 \mathrm{~m} \mathrm{~s}^{-1}$

\begin{tabular}{|c|c|c|c|}
\hline 24 & 62 & 46 & 83 \\
\hline$\underline{57}$ & 36 & 361 & 190 \\
\hline 2 & 11 & 9 & 16 \\
\hline 7 & 2 & 82 & 35 \\
\hline
\end{tabular}

B. Outer region $(100-300 \mathrm{~km})$

Fig. 5. Quadrants placed according to the direction of vertical wind shear. As in Figure 2, the top left square in each box is the downshear left quadrant. Underlined numbers highlight differences between Corbosiero and Molinari (2002) (top line of each box) and the current study (bottom line of each box).

$135^{\circ}$ (Table 3), so that the right front quadrant aligns most frequently with the downshear left quadrant. According to $\mathrm{CMO3}$, the combined effects of vertical wind shear and storm motion should produce the maximum number of convective regions in the downshear left and right front quadrants, and this is the case for the current study. The results of a chi-square test (Wilks, 1995) show that counts of the shear-motion angles that exist for each convective region compared with counts of the angles from 
Table 3. Counts of Observations Per $30^{\circ}$ Angle Measured Counterclockwise from the Vertical Wind Shear Vector to the Motion Vector

\begin{tabular}{lccc}
\hline \hline Angle, degrees & CM03 obs. periods ${ }^{\mathrm{a}}$ & This study obs. periods & $\begin{array}{c}\text { This study convective } \\
\text { regions }\end{array}$ \\
\hline $315-345$ & 19 & 11 & 26 \\
$345-15$ & 38 & 17 & 57 \\
$15-45$ & 54 & 48 & 119 \\
$45-75$ & 54 & 55 & 159 \\
$75-105$ & 39 & 45 & 170 \\
$105-135$ & 29 & 24 & 162 \\
$135-165$ & 21 & 30 & 108 \\
$165-195$ & 17 & 25 & 53 \\
$195-225$ & 16 & 25 & 27 \\
$225-255$ & 7 & 5 & 17 \\
$255-285$ & 6 & 8 & 14 \\
$285-315$ & 3 & 1 & 4 \\
Total & 303 & 294 & 916 \\
\hline
\end{tabular}

aData for CM03 are from their Figure 6.

the CM03 study have differing distributions and that this difference is statistically significant $(p<0.01)$. This finding supports the work of CM03, Rogers et al. (2003), and Chen et al. (2006), who stressed the need to consider the effects of both vertical wind shear and storm motion on the development of convective clouds within TCs.

\section{Extratropical Transition}

Nearly the same numbers of convective regions exist within ET72 TCs ( $n=451)$ as within the remaining TCs $(n=465)$. However, ET72 TCs have fewer convective regions within $100 \mathrm{~km}$ of the storm center than the remaining TCs (Fig. 6). This finding is expected, as rainfall decreases in the core due to the entrainment of cooler and/or drier air as a TC undergoes an extratropical transition (Ritchie and Elsberry, 2001; Atallah and Bosart, 2003; Jones et al., 2003). On average, convective regions within ET72 TCs are approximately $1000 \mathrm{~km}^{2}$ larger in area than those within the rest of the TCs. The convective regions for both groups are larger on average when located closer to the circulation center, which is indicative of a continuous region of convection comprising the eyewall or its remnants, while in the outer region, convective regions within the rain bands are smaller in size.

When TCs transition into extratropical cyclones, their interaction with middle latitude troughs increases their forward motion (Hanley et al., 2001; Hanley, 2002; Jones et al., 2003; Peng et al., 2007). As expected, forward velocities are higher on average $\left(6.4 \mathrm{~m} \mathrm{~s}^{-1}\right)$ for ET72 TCs than for the rest of the TCs $\left(4.2 \mathrm{~m} \mathrm{~s}^{-1}\right)$. When 

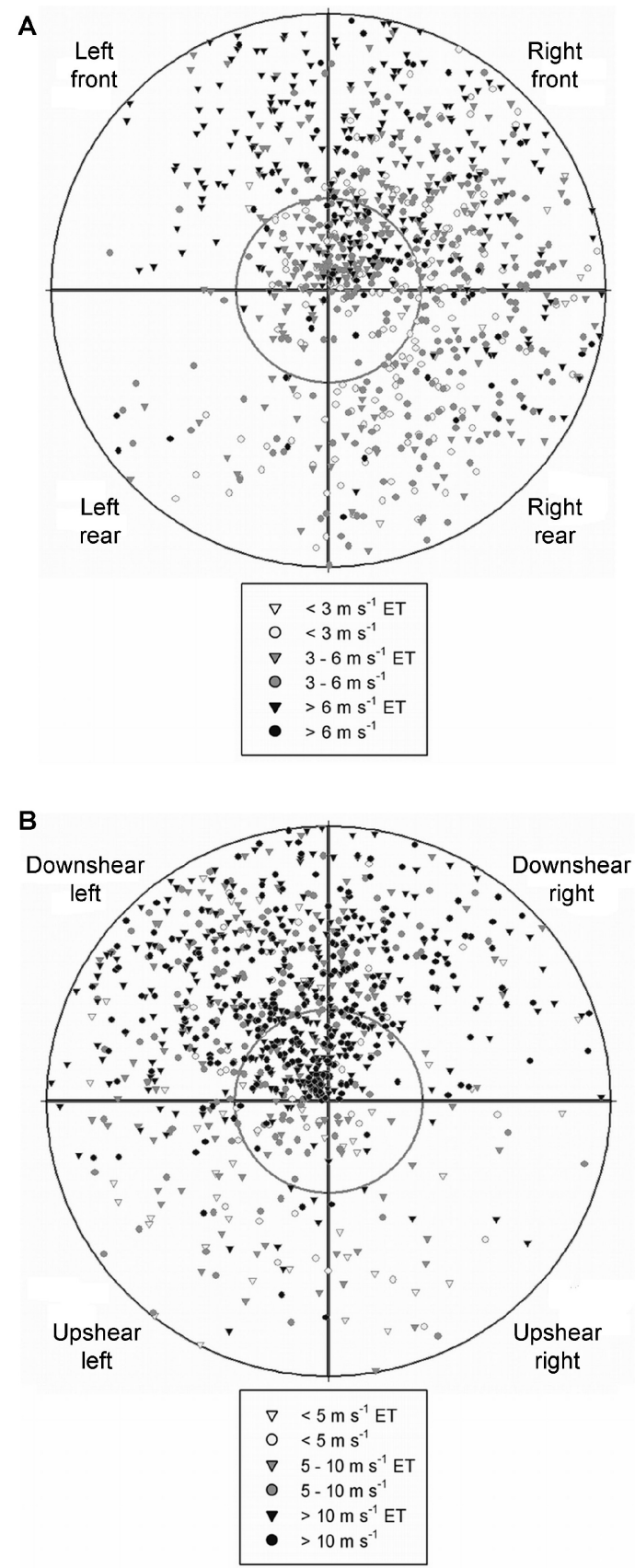

Fig. 6. Centroid locations for tropical cyclones that do and do not become extratropical (ET) 72 hours post-landfall plotted according to their distance from the circulation center of the TC and bearing relative to $(\mathrm{A})$ the forward motion of the TC and (B) direction of the vertical wind shear. The inner ring represents a $100 \mathrm{~km}$ radius from the storm center, whereas the outer ring is at a radius of $300 \mathrm{~km}$. 
observation periods are separated according to storm motion, as described earlier in the study, convection in the outer regions of ET72 TCs is greater in the right front quadrant than the right rear quadrant when forward velocity is less than $6 \mathrm{~m} \mathrm{~s}^{-1}$, while the opposite is true of the remaining storms (Fig. 6A). For fast-moving TCs, the right front quadrant has the highest percentage of convective regions in both groups, but the quadrant featuring the second highest percentage of convection is the left front (right rear) for TCs that do (do not) become extratropical within 72 hours of landfall. The difference in distribution of convection is statistically significant, as confirmed through a chi-square test comparing the number of convective regions in each quadrant for each TC group $(p<0.001)$. For TCs that transition, drier and cooler air advects into the left and then right rear quadrants to decrease rainfall behind the storm center (Atallah and Bosart, 2003; Jones et al., 2003). Yet for TCs that do not transition, rainfall may be enhanced within both right quadrants through moisture advection from low-level jets as the storm moves inland (Bluestein and Hazen, 1989; Arndt et al., 2009). This difference in the location of heavy rainfall has important implications for flood forecasting, as TCs that do not become extratropical are most likely to produce their heaviest rainfall to the right side of the storm track, while both sides of the storm track may experience heavy rainfall several hours prior to the arrival of the circulation center as TCs begin to transition.

Both ET72 and the remaining TCs experience similar average velocities of vertical wind shear (12.1 $\mathrm{m} \mathrm{s}^{-1}$ ET72, $11.9 \mathrm{~m} \mathrm{~s}^{-1}$ remaining TCs). When the convective regions are examined according to shear-relative quadrants, both groups have the highest percentage of observations within the downshear left quadrant (Fig. 6B). However, the second-highest percentage of convective regions is located in the upshear left (downshear right) quadrant within ET72 (remaining) TCs. A chi-square test shows that the difference in the shear-relative distribution of convection between the two groups is statistically significant $(p=0.002)$. The CM02 and CM03 studies only employed observation times containing high flash densities. Because the distribution of convection for TCs that do not transition into extratropical cyclones within 72 hours of landfall is more similar to that of CM02 than for the ET72 TCs, it is possible that the CM02 study contained fewer observation periods for TCs nearing their time of ET. As the current study shows that the number of convective regions within ET72 and the remaining TCs are similar, this finding implies that, while capable of producing flooding rains (Atallah and Bosart, 2003; Jones et al., 2003), TCs may produce relatively few CG flashes as they transition into extratropical cyclones.

\section{CONCLUSIONS}

This study examined areas of high radar reflectivity values for 24 hours following $45 \mathrm{TC}$ landfalls. These convective regions were identified through a spatial analysis of radar reflectivity returns within a GIS. The locations of these radar-derived convective regions were then compared to the locations of convection, as determined through an analysis of CG lightning for 35 landfalling TCs by Corbosiero and Molinari (2002, 2003). Each TC was divided into quadrants based on the direction of storm motion and heading 
of the vertical wind shear. The inner $100 \mathrm{~km}$ and outer region 100-300 km from the circulation centers were examined separately. For differing velocities of storm motion and vertical wind shear, the percentage of convective regions within each quadrant calculated for the current study was compared to the percentage of times that each quadrant contained the highest flash count as defined by $\mathrm{CMO} 2$ and CM03. TCs that became extratropical within 72 hours of landfall were also examined separately from the remaining TCs in the current study.

Both studies agreed that storm motion and vertical wind shear influenced where convective clouds developed. Convection shifted counterclockwise from the right to the front portion of the storm as forward velocity increased. Convection was located mainly left of the vertical wind shear vector when storm motion was $45-135^{\circ}$ counterclockwise from the shear vector as the right front quadrant aligned with the two left-of-shear quadrants. When shear-minus-motion angles were $315-45^{\circ}$, the majority of the convection was located in the two downshear quadrants as they aligned with the right front quadrant in these cases. For the ET72 TCs, convection was mainly located more than $100 \mathrm{~km}$ ahead of the storm center and in the two left-ofshear quadrants. Although experiencing the same velocity of vertical wind shear on average, TCs that did not complete an extratropical transition within 72 hours of landfall had slower forward velocities and more convection on the right side of the storm and in the downshear right quadrant.

The results of this study suggest that future research should utilize a GIS to explore the locations of lightning and radar-derived convective rainfall for the same group of TCs. The current study utilized Level III base reflectivity data as they were available for enough storms to rival the sample size of CM02 and CM03. Although available for fewer storms, a GIS-based analysis of Level II radar reflectivity data should be performed to identify the height of the $40 \mathrm{dBZ}$ values associated with CG flashes in numerous landfalling TCs as well as to permit three-dimensional modeling of the convective cells. Where updrafts are strong enough to produce lightning, it is likely that the CG flashes will be located in the updrafts (Molinari et al., 1999) near the highest reflectivity gradients (Barnes et al., 1991), which will be removed slightly from the center of the downdraft containing the highest reflectivity values (Marks and Houze, 1987). TCs should be analyzed utilizing both datasets as they transition into extratropical cyclones to determine whether these storms produce little lightning during their transitional phase, and whether TCs that rapidly weaken prior to their transition produce less lightning and have lower reflectivity values than those that weaken more slowly. In addition to those available from the NLDN and WSR-88D network, data from other sources such as the TRMM satellite and the long-range lightning detection network also should be utilized in future investigations of convective regions within TCs. 
Acknowledgements: The author thanks Dr. Mark DeMaria for access to the SHIPS database from which the vertical wind shear data were obtained. The comments of the anonymous reviewers were very helpful in achieving the final draft of this manuscript.

\section{REFERENCES}

Arndt, D. S., Basara, J. B., McPherson, R. A., Illston, B. G., McManus, G. D., and Demko, D. B. (2009) Observations of the overland reintensification of Tropical Storm Erin (2007). Bulletin of the American Meteorological Society, Vol. 90, 1079-1093.

Ashley, S. T. and Ashley, W. S. (2008) Flood fatalities in the United States. Journal of Applied Meteorology and Climatology, Vol. 47, 805-818.

Atallah, E. H. and Bosart, L. R. (2003) The extratropical transition and precipitation distribution of Hurricane Floyd (1999). Monthly Weather Review, Vol. 131, 1063-1081.

Barnes, G. M., Gamache, J. F., Lemone, M. A., and Stossmeister, G. J. (1991) A convective cell in a hurricane rainband. Monthly Weather Review, Vol. 119, 776-794.

Barnes, G. M., Zipser, E., Jorgensen, D., and Marks, F. D. (1983) Mesoscale and convective structure of a hurricane rainband. Journal of the Atmospheric Sciences, Vol. 40, 2125-2137.

Black, M. L., Gamache, J. F., Marks, F. D., Samsury, C. E., and Willoughby, H. E. (2002) Eastern Pacific Hurricanes Jimena of 1991 and Olivia of 1994: The effect of vertical shear on structure and intensity. Monthly Weather Review, Vol. 130, 2291-2312.

Black, R. A. and Hallett, J. (1999) Electrification of the hurricane. Journal of the Atmospheric Sciences, Vol. 56, 2004-2028.

Blackwell, K. G. (2000) Evolution of Hurricane Danny (1997) at landfall: Dopplerobserved eyewall replacement, vortex contraction/intensification, and low-level wind maxima. Monthly Weather Review, Vol. 128, 4002-4016.

Bluestein, H. B. and Hazen, D. S. (1989) Doppler-radar analysis of a tropical cyclone over land-Hurricane Alicia (1983) in Oklahoma. Monthly Weather Review, Vol. 117, 2594-2611.

Burpee, R. W. and Black, M. L. (1989) Temporal and spatial variations of rainfall near the centers of two tropical cyclones. Monthly Weather Review, Vol. 117, 2204-2218.

Cecil, D. J. (2007) Satellite-derived rain rates in vertically sheared tropical cyclones. Geophysical Research Letters, Vol. 34, L02811 [doi: 10.1029/2006GL027942].

Cecil, D. J., Goodman, S. J., Boccippio, D. J., Zipser, E. J., and Nesbitt, S. W. (2005) Three years of TRMM precipitation features. Part I: Radar, radiometric, and lightning characteristics. Monthly Weather Review, Vol. 133, 543-566.

Cecil, D. J. and Zipser, E. J. (2002) Reflectivity, ice scattering, and lightning characteristics of hurricane eyewalls and rainbands. Part II: Intercomparison of observations. Monthly Weather Review, Vol. 130, 785-801. 
Cecil, D. J., Zipser, E. J., and Nesbitt, S. W. (2002) Reflectivity, ice scattering, and lightning characteristics of hurricane eyewalls and rainbands. Part I: Quantitative description. Monthly Weather Review, Vol. 130, 769-784.

Chen, S. Y. S., Knaff, J. A., and Marks, F. D. (2006) Effects of vertical wind shear and storm motion on tropical cyclone rainfall asymmetries deduced from TRMM. Monthly Weather Review, Vol. 134, 3190-3208.

Corbosiero, K. L. and Molinari, J. (2002) The effects of vertical wind shear on the distribution of convection in tropical cyclones. Monthly Weather Review, Vol. 130, 2110-2123.

Corbosiero, K. L. and Molinari, J. (2003) The relationship between storm motion, vertical wind shear, and convective asymmetries in tropical cyclones. Journal of the Atmospheric Sciences, Vol. 60, 366-376.

Delobbe, L. and Holleman, I. (2006) Uncertainties in radar echo top heights used for hail detection. Meteorological Applications, Vol. 13, 361-374.

DeMaria, M. (1996) The effect of vertical shear on tropical cyclone intensity change. Journal of the Atmospheric Sciences, Vol. 53, 2076-2087.

DeMaria, M. and Kaplan, J. (1994) A statistical hurricane intensity prediction scheme (SHIPS) for the Atlantic basin. Weather and Forecasting, Vol. 9, 209-220.

DeMaria, M., Mainelli, M., Shay, L. K., Knaff, J. A., and Kaplan, J. (2005) Further improvements to the Statistical Hurricane Intensity Prediction Scheme (SHIPS). Weather and Forecasting, Vol. 20, 531-543.

Elsberry, R. L. (2002) Predicting hurricane landfall precipitation: Optimistic and pessimistic views from the symposium on precipitation extremes. Bulletin of the American Meteorological Society, Vol. 83, 1333-1339.

Frank, W. M. and Ritchie, E. A. (1999) Effects of environmental flow upon tropical cyclone structure. Monthly Weather Review, Vol. 127, 2044-2061.

Frank, W. M. and Ritchie, E. A. (2001) Effects of vertical wind shear on the intensity and structure of numerically simulated hurricanes. Monthly Weather Review, Vol. 129, 2249-2269.

Geerts, B., Heymsfield, G. M., Tian, L., Halverson, J. B., Guillory, A., and Mejia, M. I. (2000) Hurricane Georges's landfall in the Dominican Republic: Detailed airborne Doppler radar imagery. Bulletin of the American Meteorological Society, Vol. 81, 999-1018.

Hanley, D., Molinari, J., and Keyser, D. (2001) A composite study of the interactions between tropical cyclones and upper-tropospheric troughs. Monthly Weather Review, Vol. 129, 2570-2584.

Hanley, D. E. (2002) The evolution of a hurricane-trough interaction from a satellite perspective. Weather and Forecasting, Vol. 17, 916-926.

Hart, R. E. and Evans, J. L. (2001) A climatology of the extratropical transition of Atlantic tropical cyclones. Journal of Climate, Vol. 14, 546-564.

Jones, S. C. (1995) The evolution of vortices in vertical shear. I: Initially barotropic vortices. Quarterly Journal of the Royal Meteorological Society, Vol. 121, 821-851.

Jones, S. C. (2000) The evolution of vortices in vertical shear. III: Baroclinic vortices. Quarterly Journal of the Royal Meteorological Society, Vol. 126, 3161-3185. 
Jones, S. C., Harr, P. A., Abraham, J., Bosart, L. F., Bowyer, P. J., Evans, J. L., Hanley, D. E., Hanstrum, B. N., Hart, R. E., Lalaurette, F., Sinclair, M. R., Smith, R. K., and Thorncroft, C. (2003) The extratropical transition of tropical cyclones: Forecast challenges, current understanding, and future directions. Weather and Forecasting, Vol. 18, 1052-1092.

Jorgensen, D. P. (1984) Mesoscale and convective-scale characteristics of mature hurricanes. Part I: General observations by research aircraft. Journal of the Atmospheric Sciences, Vol. 41, 1268-1285.

Kimball, S. K. (2008) Structure and evolution of rainfall in numerically simulated landfalling hurricanes. Monthly Weather Review, Vol. 136, 3822-3847.

Knight, D. B. and Davis, R. E. (2007) Climatology of tropical cyclone rainfall in the southeastern United States. Physical Geography, Vol. 28, 126-147.

Konrad, C. E. (2001) The most extreme precipitation events over the eastern United States from 1950 to 1996: Considerations of scale. Journal of Hydrometeorology, Vol. 2, 309-325.

Konrad, C. E., Meaux, M. F., and Meaux, D. A. (2002) Relationships between tropical cyclone attributes and precipitation totals: Considerations of scale. International Journal of Climatology, Vol. 22, 237-247.

Konrad, C. E. and Perry, L. B. (2010) Relationships between tropical cyclones and heavy rainfall in the Carolina region of the USA. International Journal of Climatology, Vol. 30, 522-534.

Liu, C. T. and Zipser, E. J. (2008) Diurnal cycles of precipitation, clouds, and lightning in the tropics from 9 years of TRMM observations. Geophysical Research Letters, Vol. 35, L04819 [doi: 10.1029/2007gl032437].

Lonfat, M., Marks, F. D., and Chen, S. Y. S. (2004) Precipitation distribution in tropical cyclones using the Tropical Rainfall Measuring Mission (TRMM) Microwave Imager: A global perspective. Monthly Weather Review, Vol. 132, 1645-1660.

Lonfat, M., Rogers, R., Marchok, T., and Marks, F. D. (2007) A parametric model for predicting hurricane rainfall. Monthly Weather Review, Vol. 135, 3086-3097.

Lyons, W. A. and Keen, C. S. (1994) Observations of lightning in convective supercells within tropical storms and hurricanes. Monthly Weather Review, Vol. 122, 1897-1916.

Marks, F. D. and Houze, R. A. (1987) Inner core structure of Hurricane Alicia from airborne Doppler radar observations. Journal of the Atmospheric Sciences, Vol. 44, 1296-1317.

Matyas, C. J. (2007) Quantifying the shapes of US landfalling tropical cyclone rain shields. Professional Geographer, Vol. 59, 158-172.

Matyas, C. J. (2008) Shape measures of rain shields as indicators of changing environmental conditions in a landfalling tropical storm. Meteorological Applications, Vol. 15, 259-271.

Matyas, C. J. (2009) A spatial analysis of radar reflectivity regions within Hurricane Charley (2004). Journal of Applied Meteorology and Climatology, Vol. 48, 130-142.

Matyas, C. J. (2010) Associations between the size of hurricane rain fields at landfall and their surrounding environments Meteorology and Atmospheric Physics, Vol. $106,135-148$. 
McCaul, E. W., Buechler, D. E., Goodman, S. J., and Cammarata, M. (2004) Doppler radar and lightning network observations of a severe outbreak of tropical cyclone tornadoes. Monthly Weather Review, Vol. 132, 1747-1763.

Medlin, J. M., Kimball, S. K., and Blackwell, K. G. (2007) Radar and rain gauge analysis of the extreme rainfall during Hurricane Danny's (1997) landfall. Monthly Weather Review, Vol. 135, 1869-1888.

Milrad, S. M., Atallah, E. H., and Gyakum, J. R. (2009) Dynamical and precipitation structures of poleward-moving tropical cyclones in eastern Canada, 1979-2005. Monthly Weather Review, Vol. 137, 836-851.

Molinari, J., Moore, P., and Idone, V. (1999) Convective structure of hurricanes as revealed by lightning locations. Monthly Weather Review, Vol. 127, 520-534.

Molinari, J., Moore, P. K., Idone, V. P., Henderson, R. W., and Saljoughy, A. B. (1994) Cloud-to-ground lightning in Hurricane Andrew. Journal of Geophysical Research-Atmospheres, Vol. 99, 16,665-16,676.

Murphy, M. S. and Konrad, C. E. (2005) Spatial and temporal patterns of thunderstorm events that produce cloud-to-ground lightning in the interior southeastern United States. Monthly Weather Review, Vol. 133, 1417-1430.

Nesbitt, S. W., Cifelli, R., and Rutledge, S. A. (2006) Storm morphology and rainfall characteristics of TRMM precipitation features. Monthly Weather Review, Vol. $134,2702-2721$.

Nesbitt, S. W., Zipser, E. J., and Cecil, D. J. (2000) A census of precipitation features in the tropics using TRMM: Radar, ice scattering, and lightning observations. Journal of Climate, Vol. 13, 4087-4106.

NSSL, 2006, Thunderstorm basics. Retrieved August 28, 2010 from the National Severe Storms Lab at http://www.nssl.noaa.gov/primer/tstorm/tst_basics.html

OFCM (2006) Federal Meteorological Handbook, No. 11: Doppler Radar Meteorological Observations. Part D, WSR-88D unit description and operational applications. Washington, DC: U.S. Department of Commerce, No. 11.

Parker, M. D. and Knievel, J. C. (2005) Do meteorologists suppress thunderstorms? Radar-derived statistics and the behavior of moist convection. Bulletin of the American Meteorological Society, Vol. 86, 341-358.

Parrish, J. R., Burpee, R. W., Marks, F. D., and Grebe, R. (1982) Rainfall patterns observed by digitized radar during the landfall of Hurricane Frederic (1979). Monthly Weather Review, Vol. 110, 1933-1944.

Peng, M. S., Maue, R. N., Reynolds, C. A., and Langland, R. H. (2007) Hurricanes Ivan, Jeanne, Karl (2004) and mid-latitude trough interactions. Meteorology and Atmospheric Physics, Vol. 97, 221-237.

Powell, M. D. (1987) Changes in the low-level kinematic and thermodynamic structure of Hurricane Alicia (1983) at landfall. Monthly Weather Review, Vol. 115, 75-99.

Proctor, D. E. (1991) Regions where lightning flashes began. Journal of Geophysical Research-Atmospheres, Vol. 96, 5099-5112.

Rappaport, E. N. (2000) Loss of life in the United States associated with recent Atlantic tropical cyclones. Bulletin of the American Meteorological Society, Vol. 81, 2065-2073. 
Ritchie, E. A. and Elsberry, R. L. (2001) Simulations of the transformation stage of the extratropical transition of tropical cyclones. Monthly Weather Review, Vol. 129, 1462-1480.

Rogers, R. F., Chen, S. S., Tenerelli, J., and Willoughby, H. E. (2003) A numerical study of the impact of vertical shear on the distribution of rainfall in Hurricane Bonnie (1998). Monthly Weather Review, Vol. 131, 1577-1599.

Samsury, C. E. and Orville, R. E. (1994) Cloud-to-ground lightning in tropical cyclones-a study of Hurricanes Hugo (1989) and Jerry (1989). Monthly Weather Review, Vol. 122, 1887-1896.

Schumacher, R. S. and Johnson, R. H. (2006) Characteristics of US extreme rain events during 1999-2003. Weather and Forecasting, Vol. 21, 69-85.

Shapiro, L. J. (1983) The asymmetric boundary-layer flow under a translating hurricane. Journal of the Atmospheric Sciences, Vol. 40, 1984-1998.

Shepherd, J. M., Grundstein, A., and Mote, T. L. (2007) Quantifying the contribution of tropical cyclones to extreme rainfall along the coastal southeastern United States. Geophysical Research Letters, Vol. 34, 5.

Squires, K. and Businger, S. (2008) The morphology of eyewall lightning outbreaks in two category 5 hurricanes. Monthly Weather Review, Vol. 136, 1706-1726.

Steiger, S. M., Orville, R. E., and Carey, L. D. (2007) Lightning signatures of thunderstorm intensity over North Texas. Part I: Supercells. Monthly Weather Review, Vol. $135,3281-3302$.

Tapia, A., Smith, J. A., and Dixon, M. (1998) Estimation of convective rainfall from lightning observations. Journal of Applied Meteorology, Vol. 37, 1497-1509.

Tootle, G., Mirti, T., and Piechota, T. (2005) Technical Notes: Magnitude and return period of 2004 hurricane rainfall in Florida. Journal of Floodplain Management, Vol. 5, 32-37.

Toracinta, E. R., Cecil, D. J., Zipser, E. J., and Nesbitt, S. W. (2002) Radar, passive microwave, and lightning characteristics of precipitating systems in the tropics. Monthly Weather Review, Vol. 130, 802-824.

Toracinta, E. R., Mohr, K. I., Zipser, E. J., and Orville, R. E. (1996) A comparison of WSR-88D reflectivities, SSM/I brightness temperatures, and lightning for mesoscale convective systems in Texas. 1: Radar reflectivity and lightning. Journal of Applied Meteorology, Vol. 35, 902-918.

Wakimoto, R. M. and Black, P. G. (1994) Damage survey of Hurricane Andrew and its relationship to the eyewall. Bulletin of the American Meteorological Society, Vol. 75, 189-200.

Wang, D., Li, X. F., Tao, W. K., and Wang, Y. (2009) Effects of vertical wind shear on convective development during a landfall of severe tropical storm Bilis (2006). Atmospheric Research, Vol. 94, 270-275.

Wilks, D. S. (1995) Statistical Methods in the Atmospheric Sciences. San Diego, CA: Academic Press.

Williams, C. R., Gage, K. S., Clark, W., and Kucera, P. (2005) Monitoring the reflectivity calibration of a scanning radar using a profiling radar and a disdrometer. Journal of Atmospheric and Oceanic Technology, Vol. 22, 1004-1018. 
Williams, E. R., Rutledge, S. A., Geotis, S. G., Renno, N., Rasmussen, E., and Rickenbach, T. (1992) A radar and electrical study of tropical hot towers. Journal of the Atmospheric Sciences, Vol. 49, 1386-1395.

Willoughby, H. E., Marks, F. D., and Feinberg, R. J. (1984) Stationary and moving convective bands in hurricanes. Journal of the Atmospheric Sciences, Vol. 41, 3189-3211.

Yokoyama, C. and Takaybu, Y. N. (2007) A statistical study on rain characteristics of tropical cyclones using TRMM satellite data. Geophysical Research Abstracts, Vol. 9, abs. no. 07260.

Zhang, J., Howard, K., and Gourley, J. J. (2005) Constructing three-dimensional multiple-radar reflectivity mosaics: Examples of convective storms and stratiform rain echoes. Journal of Atmospheric and Oceanic Technology, Vol. 22, 30-42.

Zipser, E. J. and Lutz, K. R. (1994) The vertical profile of radar reflectivity of convective cells-a strong indicator of storm intensity and lightning probability. Monthly Weather Review, Vol. 122, 1751-1759. 